\title{
Distribution, morphology, and morphometry of circular mounds in the elongated basin of northern Terra Sirenum, Mars
}

Ryodo Hemmi and Hideaki Miyamoto*

\begin{abstract}
An elongated, flat-floored basin, located in the northern part of Terra Sirenum on Mars, holds numerous enigmatic mounds (100 $\mathrm{m}$ wide) on the surface of its floor. We investigated their geological context, spatial distribution, morphological characteristics, and morphometric parameters by analyzing a variety of current remote sensing data sets of Mars. Over 700 mounds are identified; mapping of the mounds shows the spatial density of about 21 per $100 \mathrm{~km}^{2}$ and appearances of several clusters, coalescence, and/or alignment. Most of the mounds have smoother surface textures in contrast to the rugged surrounding terrain. Some of the mounds display depressions on their summits, meter-sized boulders on their flanks, and distinct lobate features. We also perform high-resolution topographic analysis on 50 isolated mounds, which reveals that their heights range from 6 to $43 \mathrm{~m}$ with a mean of $18 \mathrm{~m}$ and average flank slopes of most mounds are below $10^{\circ}$. These characteristics are consistent with the deposition and extension of mud slurries with mud breccia and gases extruded from subsurface, almost equivalent to terrestrial mud volcanism. If so, both abundance of groundwater and abrupt increase in pore fluid pressure are necessary for triggering mud eruption. Absolute crater retention ages suggest that the floor of the basin located among middle Noachian-aged highland terrains has been resurfaced during the Late Hesperian Epoch. Because of cross-cutting relationships with the basin and the mounds superposed on the basin floor, the faults and fissures (part of Memnonia Fossae) are thought to have formed during and/or after the period of mound formation. Compressional stress fields which likely formed Memnonia Fossae and Mangala Valles, expected from the dike emplacement model of Wilson and Head (JGR 107:1-1-1-24, 2002), may have facilitated undercompaction or overpressurization of subsurface fluids, focused pore fluids beneath the basin, and opened conduits along faults for upwelling voluminous sediments and fluids.
\end{abstract}

Keywords: Mars, Terra Sirenum, Remote sensing, Mud volcanism

\section{Introduction}

Across the southern highlands of Mars, potential groundwater and/or hydrothermal circulation during the Noachian to Hesperian or possibly Amazonian ages has been repeatedly suggested, as evidenced by the morphology of valley networks, regional fissures and associated fluvial channels (e.g., Tanaka and Chapman 1990; Wilson and Head 2002), and distinct spectral signatures of phyllosilicates, chlorides, and sulfates (e.g., Glotch et al. 2010; Wray et al. 2011; Michalski et al. 2017). However,

\footnotetext{
* Correspondence: hm@sys.t.u-tokyo.ac.jp

Department of Systems Innovation, School of Engineering, The University of Tokyo, 7-3-1 Hongo, Bunkyo-ku, Tokyo 113-8656, Japan
}

fluxes of groundwater and surface water, the interaction between groundwater activity and heat flux, the presence of a purported cryosphere (Clifford and Parker 2001) or subsurface clathrate of carbon dioxide and methane, and the timing of a halt of possible groundwater activity or whether liquid water is still extant, remain uncertain.

On early Mars (Noachian to Hesperian Periods with approximate absolute age ranging from 4.1 to $3.1 \mathrm{Gyr}$ (Tanaka et al. 2014)), groundwater/hydrothermal systems, estimated from the presence of clay minerals on a global scale (Ehlmann et al. 2013), may have occurred, with diverse evidence including a number of putative mud volcanoes being reported in both the northern 
lowlands (e.g, Tanaka et al. 2005) and relatively old, southern highlands (e.g., Pondrelli et al. 2011; Okubo 2016). However, the spatial extent of potential mud volcanism on Mars has yet to be fully understood. Moreover, criteria for distinguishing between mud volcanoes and other morphologically similar landforms (e.g., cinder cones, tuff cones, rootless cones, pingos) have yet to be established.

Our study area, an unnamed NNE-SSW elongated depression $\left(25-28^{\circ} \mathrm{S}, 203-205^{\circ} \mathrm{W} ; \sim 150 \mathrm{~km}\right.$ long, $<\sim 50 \mathrm{~km}$ wide), is located on the northern part of Terra Sirenum in the southern highlands of Mars (Fig. 1). This basin was previously mapped as the middle or early Noachian-aged highland units (mNh and eNh units; Tanaka et al. (2014)) which are the same geological units as the surrounding cratered terrain. Based on the analysis of high-resolution hyperspectral data, Wray et al. (2011) suggested that these surrounding impact basins, especially Columbus and Cross craters, contain light-toned layered deposits including sulfates and phyllosilicate minerals, which imply the deep paleolakes, fed by upwelling groundwater, may have existed and formed these deposits during the late Noachian period.

The southern part of Memnonia Fossae, one of the largest graben systems that radially extended from the Tharsis rise, traverses the basin from east to west, where dike intrusions and associated melting of cryosphere may have occurred along these faults (Wilson and Head 2002),

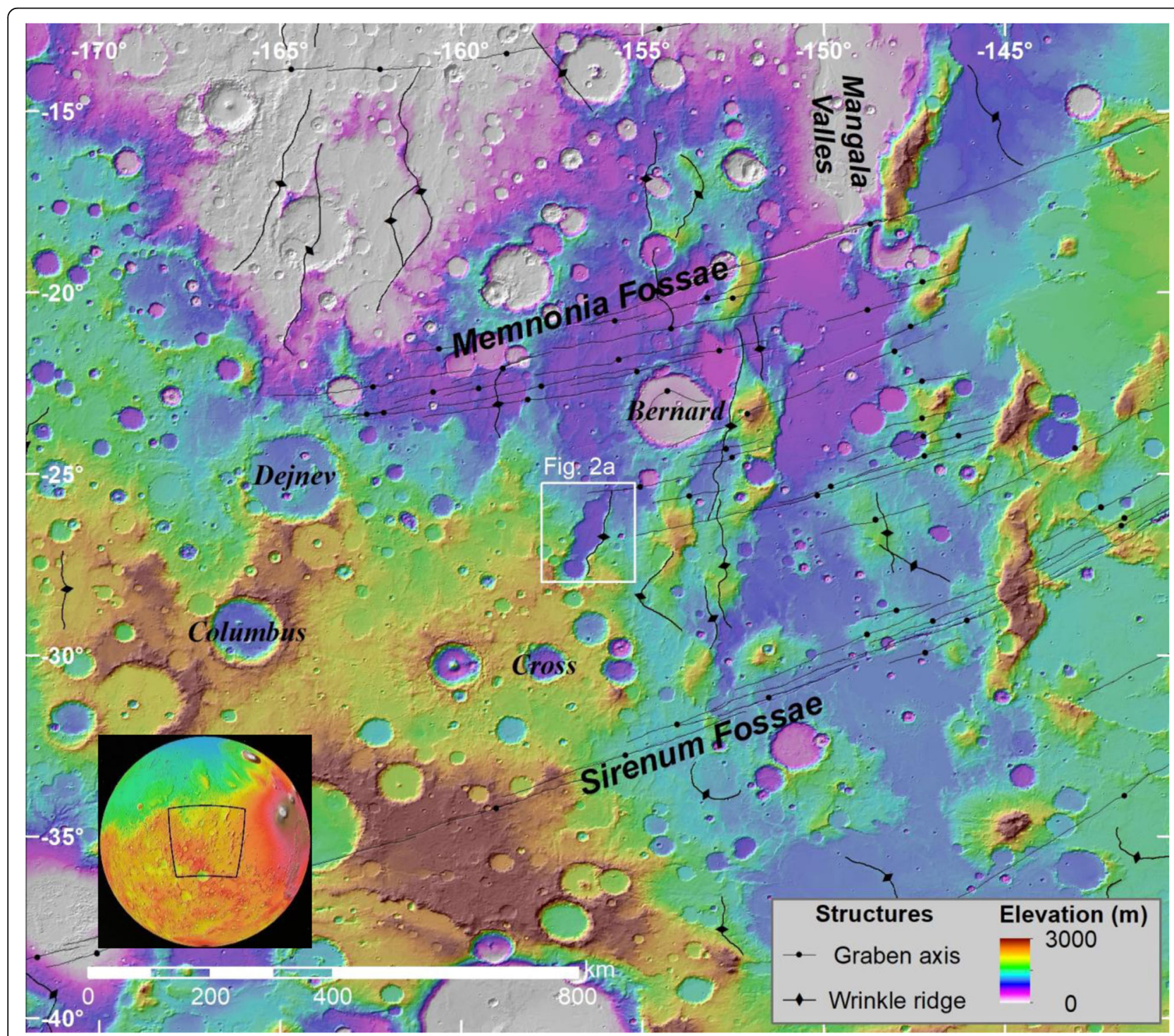

Fig. 1 Color-coded topographic map of the northern part of Terra Sirenum. Base map is the gridded MOLA topography data (512 pixels/degree) overlying the corresponding MOLA-shaded relief map (Smith et al. 2001) in simple cylindrical projection. Regional structures, interpreted by Tanaka et al. (2014), are drawn as solid black lines with symbols. A white rectangle indicates the location of Fig. 2. The inset shows the location of the study area on MOLA global topography map rendered with the Google Earth 
which is supported by the presence of Mangala Valles, the major outflow channel sourced from the northern Memnonia Fossae. Cross-cutting relationship between Memnonia Fossae and the basin shows the activity of Memnonia Fossae followed the basin formation. Wrinkle ridges, with N-S trending axis observed around this region, indicate the circum-Tharsis W-E compressional fields (Head et al. 2002), possibly associated with the Tharsis rise formation on global scale.

The shape of the elongated basin appears to be a chain of several circular sub-basins with flat floors (Fig. 2). This may indicate the integration of multiple impact craters caused by erosional processes with subsequent crater-filling depositions. Profiles of global topography model (Fig. 2c) show that inside of the basin has a mostly flat-floored surface with a slight variation in elevation (between 800 and $900 \mathrm{~m}$ in altitude) surrounded by the mountain ranges with altitudes of more than $1200 \mathrm{~m}$ (except the northern part of the basin), while the terrain outside of the basin has an inclined topography on a regional scale: the south of the basin has relatively high altitudes $(\sim 2000 \mathrm{~m})$ than the north $(\sim 1000 \mathrm{~m})$. No obvious fluvial channel into this basin exists.

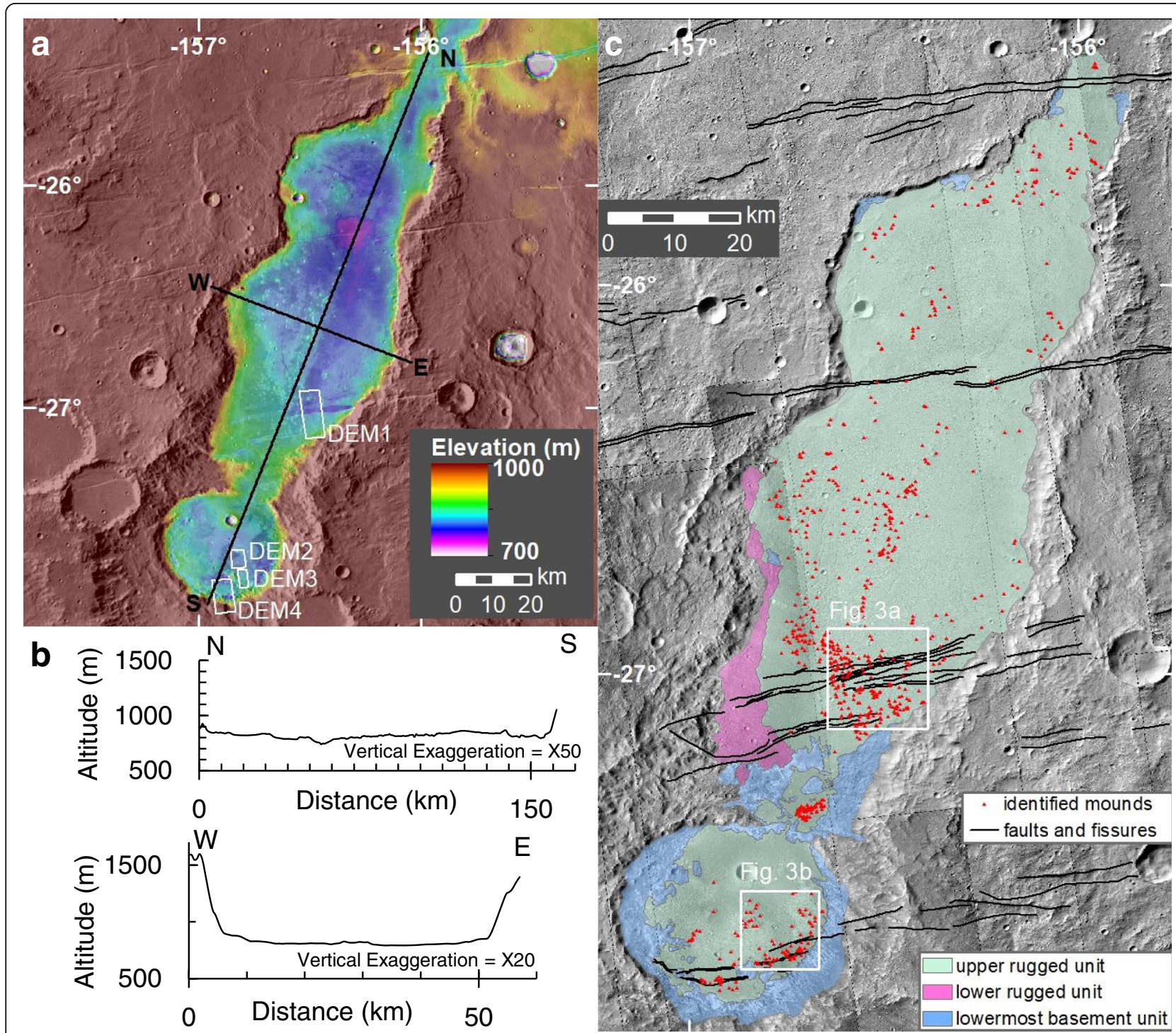

Fig. 2 Close-up view of the study area, the floor of an elongated basin. a Color-coded MOLA topography data (463 m/pixel) of the study area, underlain by THEMIS daytime infrared image (100 m/pixel). The elevation range is stretched to enhance the variation in elevation change inside the basin floor. Black solid lines ( $\mathrm{N}-\mathrm{S}$ and $\mathrm{W}-\mathrm{E}$ ) represent the locations of topographic profiles in panel $\mathbf{b}$. White rectangles indicate the footprints of four DEMs generated in this study (DEM1 to DEM4; Fig. 7). b Cross-sectional topographic profiles of the basin, extracted from the MOLA topography model in panel a. c Geology map of the study area. The surface of this area has been classified into three units. Identified faults and fissures constitute a part of Memnonia Fossae. The base image, a mosaic of CTX images, was utilized for the geological mapping 
Numerous well-preserved circular mounds are distributed inside this basin floor (Fig. 3), which contrasts to other neighboring regions on Terra Sirenum. Recently acquired high-resolution images enable us to characterize their stratigraphy, morphology, and morphometry. Thus, this study focuses on the characterization of the circular mounds on the elongated basin to reveal their formational mechanisms and their relation to the occurrence of the basin and regional geological structures. We propose that development of faults facilitated the migration and overpressurization of subsurface fluids and triggered mud extrusions. This would lead to better understanding of the evolution of hydrology and structural geology across Terra Sirenum and the assessment of its astrobiological potential.

\section{Methods/Experimental}

Data sets and processing tools

The following data products are used in this study (mostly as Geographic Information System (GIS) data sets provided by the NASA Planetary Data System, Arizona State University, University of Arizona and the United States Geological Survey (USGS) database): the Mars Odyssey's Thermal Emission Imaging System (THEMIS; Christensen et al. 2004) daytime infrared image mosaic for geological mapping and crater counting at $100 \mathrm{~m} /$ pixel, the Mars Global Surveyor (MGS) Mars Orbiter Laser Altimeter (MOLA; Smith et al. 2001) high-accuracy altimetry profile data (or Precision Experiment Data Records (PEDRs)) for the alignment of digital elevation models (DEMs) to Mars global topography, MOLA global topography models at 128 pixels per degree (also known as Mission Experiment Gridded Data Records, or MEGDRs) for examining the regional topography (Fig. 1), and the Mars Reconnaissance Orbiter's (MRO) Context Camera (CTX; Malin et al. (2007)) images at 5-6 m/pixel for geological mapping and the generation of DEMs, and MRO High Resolution Imaging Science Experiment (HiRISE; McEwen et al. (2007)) images at up to $\sim 25 \mathrm{~cm} /$ pixel

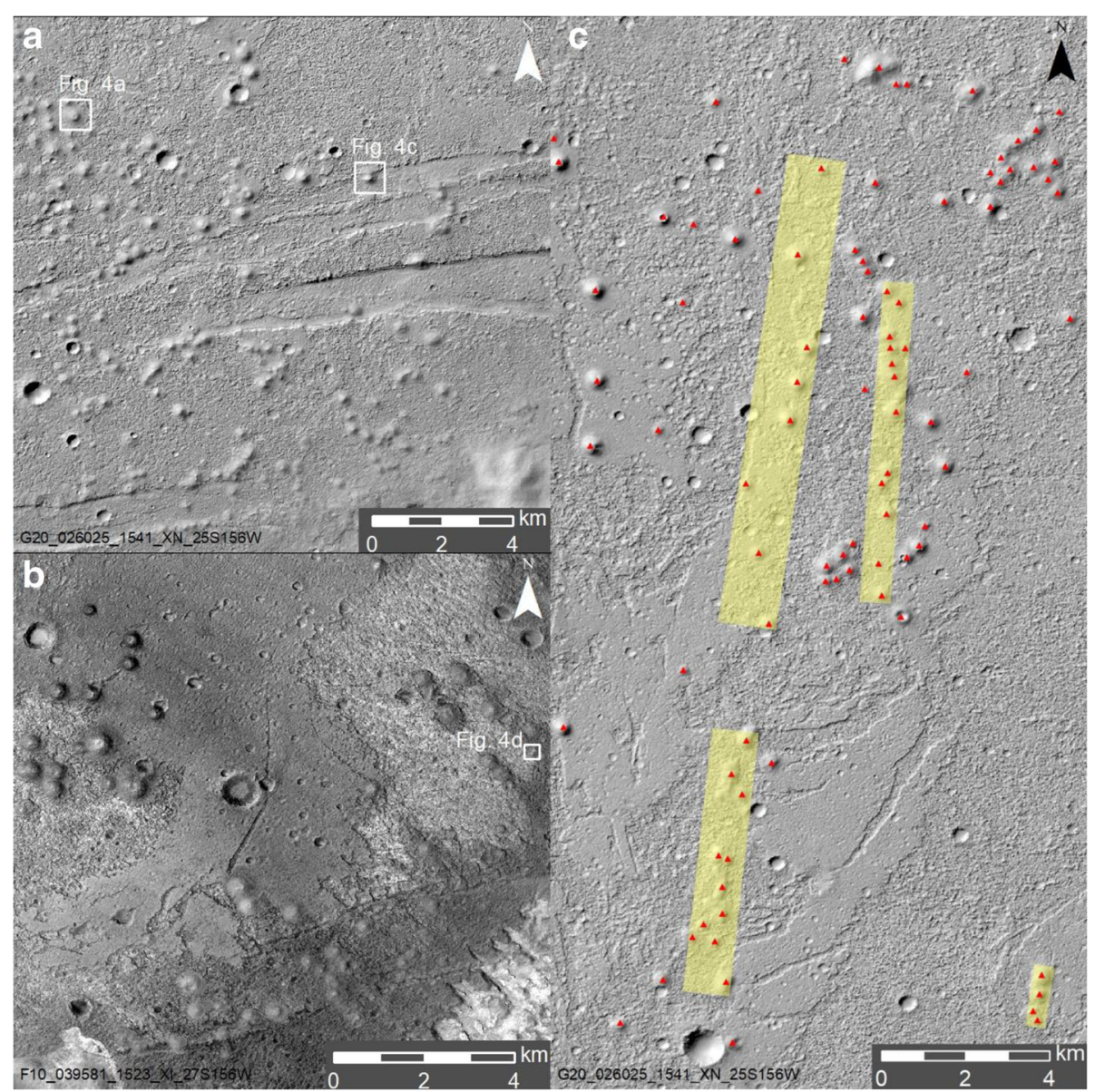

Fig. 3 Example of the mound fields. a Mounds located in the middle part of the upper rugged unit. Illumination from the upper left. Part of CTX image. $\mathbf{b}$ Mounds located in the southern part of the upper rugged unit. Illumination from the upper left. Part of CTX image. $\mathbf{c}$ Interpreted areas of the alignments (yellow rectangles) of the mounds (red triangles) 
for the identification of small-scale morphologies and the generation of DEMs. The Java Mission-planning and Analysis for Remote Sensing (JMARS; https://jmars.asu.edu/) software developed by Arizona State University, the USGS Integrated Software for Imagers and Spectrometers (ISIS; https://isis.astrogeology.usgs.gov//) and the ESRI ArcGIS 10.2, and the Geospatial Data Abstraction Library (GDAL) were mainly utilized for browsing the datasets, processing raw data products, and analyzing the image data on the GIS platform.

\section{Generation of Digital Elevation Models}

The workflow of creating high-resolution DEMs and orthoimages is twofold: (1) generating CTX-derived DEMs (18 m post-spacing) tied to MOLA PEDRs and a cartographically controlled mosaic of THEMIS daytime infrared images (Fergason et al. 2013) and (2) making HiRISE-derived DEMs ( 1 or $2 \mathrm{~m}$ post-spacing) tied to the CTX-derived DEMs. In either step, photometric calibration, bundle adjustment based on the ground control points collected from the THEMIS mosaic or CTXderived DEMs with orthoimages, and map projection of stereo images were performed using ISIS's applications, and then, stereophotogrammetric triangulation, orthorectification, and the alignment of the CTX-derived DEMs to MOLA PEDR were performed with the NASA Ames Stereo Pipeline (ASP) (Broxton and Edwards 2008; Moratto et al. 2010; Beyer et al. 2014; Shean et al. 2016). In this study, a total of two CTX-derived DEMs (used only for co-registration of HiRISE-derived DEMs) and four HiRISE-derived DEMs were extracted (Table 1). Vertical accuracy (or expected precision) of each DEM is in the range of 0.19 to $0.90 \mathrm{~m}$, which has been calculated from the product of 0.2 pixel (stereo matching error) and maximum image resolution between the two images, divided by the parallax-height ratio (e.g., Kirk et al. 2008; Becker et al., 2015; Beddingfield et al. 2015).

\section{Measurements of geometric parameters of mounds}

Morphometric parameters (basal diameters and maximum mound heights) of the 50 (sub-)circular mounds were measured using four HiRISE-derived DEMs. Each of the mounds, confirmed in the orthoimages overlaid with the DEMs, was manually delineated using ArcGIS, and then, the mean elevation values along the outlines and the areas and the maximum elevation values inside each outline were measured. Basal diameter and maximum mound height were defined as the diameter of the circle area equivalent to the measured area and the difference between the maximum and mean elevation values, respectively. Highly degraded mounds, irregularly shaped mounds, coalesced mounds, mounds superposed on highly inclined substrata, mounds less than a hundred meters diameter (equivalent to only 5 or 10 DEM pixels), and mounds outside of the valid DEMs were excluded for the measurements due to the difficulty of identifying their outlines and increasing the uncertainty in morphometric parameters. Considering the horizontal resolution and vertical accuracy of each DEM and the variability of manual outlining, errors in basal diameters and maximum mound heights are estimated to be at most $\pm 8 \mathrm{~m}$ and $\pm 2.0 \mathrm{~m}$, respectively.

Moreover, statistics of slope angles of each mound (mean, minimum, maximum, standard deviation) were also examined using the slope maps (maximum gradient values per pixel scale, in degrees) directly converted from HiRISE-derived DEMs (Table 2). For some mounds, we also extracted the topographic profiles of some mounds in cross-sections as well using the ArcGIS 3D analyst tool.

\section{Estimates of surface formation ages}

We followed the commonly accepted techniques of statistical analysis of impact craters on planetary bodies, crater size-frequency distribution (CSFD) (Crater Analysis Techniques Working Group 1979), to estimate the absolute model ages of the formation of the target areas. For mapping and measuring the impact craters on the targeted areas in THEMIS and CTX images, we used the CraterTools software (Kneissl et al. 2011) on the

Table 1 List of the details of four HiRISE-derived DEMs and two CTX-derived DEMs generated in this study

\begin{tabular}{|c|c|c|c|c|c|c|c|}
\hline \multirow[t]{3}{*}{ DEM ID } & \multirow{3}{*}{$\begin{array}{l}\text { Spatial } \\
\text { resolution } \\
\text { (m/post) }\end{array}$} & \multirow{3}{*}{$\begin{array}{l}\text { Vertical } \\
\text { accuracy } \\
\text { (m) }\end{array}$} & \multicolumn{5}{|c|}{ Stereo pairs used for the generation of DEMs } \\
\hline & & & \multicolumn{2}{|l|}{ Image 1} & \multicolumn{2}{|l|}{ Image 2} & \multirow{2}{*}{$\begin{array}{l}\text { Parallax- } \\
\text { height } \\
\text { ratio }\end{array}$} \\
\hline & & & Image ID & $\begin{array}{l}\text { Resolution } \\
\text { (m/pixel) }\end{array}$ & Image ID & $\begin{array}{l}\text { Resolution } \\
\text { (m/pixel) }\end{array}$ & \\
\hline$\overline{D E M 1}$ & 2.0 & 0.24 & ESP_047862_1525 & 0.53 & ESP_048152_1525 & 0.52 & 0.435 \\
\hline DEM2 & 2.0 & 0.90 & ESP_039370_1520 & 0.51 & ESP_039581_1520 & 0.25 & 0.085 \\
\hline DEM3 & 1.0 & 0.55 & ESP_039581_1520 & 0.25 & ESP_047150_1520 & 0.26 & 0.093 \\
\hline DEM4 & 2.0 & 0.19 & ESP_040293_1520 & 0.55 & ESP_047506_1520 & 0.26 & 0.416 \\
\hline CTX_DEM1 & 18 & 2.17 & F10_039726_1522_XI_27S156W & 5.56 & F11_040003_1522_XI_27S156W & 5.31 & 0.485 \\
\hline CTX_DEM2 & 18 & 12.02 & F09_039370_1524_XI_27S156W & 5.13 & F10_039581_1523_XI_27S156W & 5.09 & 0.084 \\
\hline
\end{tabular}


Table 2 Geometric parameters of 50 mounds measured in this study

\begin{tabular}{|c|c|c|c|c|c|c|c|c|c|c|}
\hline \multirow{2}{*}{$\begin{array}{l}\text { DEM used for } \\
\text { measurement }\end{array}$} & \multirow[t]{2}{*}{ Mound ID } & \multirow{2}{*}{$\begin{array}{l}\text { Center } \\
\left.\text { latitude ( }{ }^{\circ} \mathrm{N}\right)\end{array}$} & \multirow{2}{*}{$\begin{array}{l}\text { Center } \\
\left.\text { longitude ( }{ }^{\circ} \mathrm{E}\right)\end{array}$} & \multirow{2}{*}{$\begin{array}{l}\text { Basal } \\
\text { diameter (m) }\end{array}$} & \multirow{2}{*}{$\begin{array}{l}\text { Maximum } \\
\text { height }(m)\end{array}$} & \multirow{2}{*}{$\begin{array}{l}\text { Height- } \\
\text { width } \\
\text { ratio }\end{array}$} & \multicolumn{4}{|c|}{ Slope angles $\left({ }^{\circ}\right)$} \\
\hline & & & & & & & Maximum & Minimum & Median & $\mathrm{SD}$ \\
\hline DEM1 & Mound1_1 & -26.9533 & -156.5379 & 284 & 21.5 & 0.076 & 35.8 & 0.2 & 9.8 & 3.3 \\
\hline DEM1 & Mound1_2 & -26.9606 & -156.5390 & 165 & 8.6 & 0.052 & 35.0 & 0.3 & 6.6 & 2.3 \\
\hline DEM1 & Mound1_3 & -26.9645 & -156.5376 & 234 & 13.4 & 0.057 & 58.2 & 0.3 & 8.2 & 3.7 \\
\hline DEM1 & Mound1_4 & -26.9673 & -156.5329 & 395 & 22.2 & 0.056 & 51.8 & 0.1 & 9.9 & 4.7 \\
\hline DEM1 & Mound1_5 & -26.9768 & -156.5351 & 420 & 35.5 & 0.084 & 58.1 & 0.1 & 11.6 & 4.5 \\
\hline DEM1 & Mound1_6 & -26.9508 & -156.5083 & 160 & 7.3 & 0.046 & 14.5 & 0.1 & 5.7 & 2.4 \\
\hline DEM1 & Mound1_7 & -26.9594 & -156.5057 & 442 & 42.9 & 0.097 & 48.6 & 0.1 & 13.0 & 5.0 \\
\hline DEM1 & Mound1_8 & -27.0061 & -156.5324 & 324 & 26.5 & 0.082 & 47.9 & 0.1 & 11.2 & 4.0 \\
\hline DEM1 & Mound1_9 & -27.0232 & -156.4857 & 205 & 12.7 & 0.062 & 33.9 & 0.1 & 7.9 & 3.1 \\
\hline DEM1 & Mound1_10 & -27.0236 & -156.4804 & 367 & 26.6 & 0.072 & 66.0 & 0.1 & 10.0 & 4.5 \\
\hline DEM1 & Mound1_11 & -27.0424 & -156.5225 & 260 & 17.5 & 0.067 & 17.9 & 0.1 & 8.9 & 3.0 \\
\hline DEM1 & Mound1_12 & -27.0478 & -156.5259 & 205 & 10.6 & 0.052 & 18.2 & 0.2 & 6.9 & 2.8 \\
\hline DEM1 & Mound1_13 & -27.0521 & -156.5224 & 200 & 11.6 & 0.058 & 35.8 & 0.1 & 6.9 & 3.3 \\
\hline DEM1 & Mound1_14 & -27.0504 & -156.5158 & 217 & 11.1 & 0.051 & 17.2 & 0.0 & 7.8 & 3.7 \\
\hline DEM1 & Mound1_15 & -27.0428 & -156.5069 & 203 & 12.6 & 0.062 & 67.0 & 0.2 & 8.1 & 2.9 \\
\hline DEM1 & Mound1_16 & -27.0316 & -156.4589 & 404 & 28.6 & 0.071 & 49.4 & 0.0 & 10.0 & 4.2 \\
\hline DEM1 & Mound1_17 & -27.0554 & -156.4517 & 271 & 18.8 & 0.070 & 22.9 & 0.0 & 8.8 & 3.2 \\
\hline DEM1 & Mound1_18 & -27.0659 & -156.4866 & 367 & 31.6 & 0.086 & 54.4 & 0.0 & 10.6 & 4.0 \\
\hline DEM1 & Mound1_19 & -27.0683 & -156.4712 & 343 & 21.1 & 0.062 & 34.0 & 0.0 & 7.3 & 3.4 \\
\hline DEM1 & Mound1_20 & -27.0747 & -156.4829 & 238 & 17.0 & 0.071 & 18.7 & 0.3 & 9.1 & 2.5 \\
\hline DEM1 & Mound1_21 & -27.0810 & -156.4814 & 331 & 28.7 & 0.087 & 41.8 & 0.2 & 10.8 & 3.6 \\
\hline DEM1 & Mound1_22 & -27.0836 & -156.4749 & 345 & 25.2 & 0.073 & 33.6 & 0.1 & 9.4 & 3.5 \\
\hline DEM1 & Mound1_23 & -27.0843 & -156.4679 & 249 & 15.3 & 0.062 & 24.4 & 0.0 & 8.3 & 3.1 \\
\hline DEM1 & Mound1_24 & -27.0878 & -156.4687 & 184 & 11.7 & 0.063 & 27.8 & 0.2 & 7.5 & 3.0 \\
\hline DEM1 & Mound1_25 & -27.0851 & -156.4642 & 184 & 11.9 & 0.064 & 24.7 & 0.1 & 8.5 & 3.3 \\
\hline DEM1 & Mound1_26 & -27.0812 & -156.4620 & 328 & 24.5 & 0.075 & 35.3 & 0.0 & 9.3 & 3.0 \\
\hline DEM1 & Mound1_27 & -27.0741 & -156.4570 & 212 & 15.3 & 0.072 & 20.2 & 0.1 & 8.3 & 3.1 \\
\hline DEM1 & Mound1_28 & -27.0893 & -156.4569 & 391 & 30.1 & 0.077 & 36.2 & 0.2 & 9.4 & 3.4 \\
\hline DEM1 & Mound1_29 & -27.0903 & -156.4467 & 237 & 13.1 & 0.055 & 68.0 & 0.0 & 8.2 & 4.3 \\
\hline DEM1 & Mound1_30 & -27.0867 & -156.5048 & 230 & 7.8 & 0.034 & 43.2 & 0.1 & 5.5 & 3.1 \\
\hline DEM1 & Mound1_31 & -27.0994 & -156.5155 & 336 & 23.6 & 0.070 & 58.2 & 0.1 & 9.2 & 3.2 \\
\hline DEM1 & Mound1_32 & -27.0982 & -156.5081 & 214 & 9.1 & 0.043 & 23.9 & 0.1 & 5.9 & 2.5 \\
\hline DEM1 & Mound1_33 & -27.1091 & -156.5083 & 209 & 12.6 & 0.060 & 17.3 & 0.3 & 7.9 & 2.5 \\
\hline DEM1 & Mound1_34 & -27.1069 & -156.4880 & 270 & 17.4 & 0.065 & 18.7 & 0.1 & 8.6 & 2.7 \\
\hline DEM1 & Mound1_35 & -27.0951 & -156.4716 & 286 & 17.6 & 0.062 & 26.6 & 0.2 & 7.9 & 2.7 \\
\hline DEM1 & Mound1_36 & -27.0999 & -156.4687 & 276 & 16.2 & 0.059 & 31.2 & 0.1 & 7.9 & 3.4 \\
\hline DEM1 & Mound1_37 & -27.1021 & -156.4605 & 190 & 8.5 & 0.045 & 17.3 & 0.1 & 5.7 & 2.3 \\
\hline DEM2 & Mound2_1 & -27.6464 & -156.8530 & 392 & 28.8 & 0.073 & 66.0 & 0.1 & 12.6 & 6.4 \\
\hline DEM2 & Mound2_2 & -27.6443 & -156.8323 & 301 & 20.3 & 0.067 & 51.1 & 0.0 & 10.0 & 4.9 \\
\hline DEM2 & Mound2_3 & -27.7031 & -156.8175 & 253 & 19.0 & 0.075 & 59.0 & 0.1 & 11.1 & 6.4 \\
\hline DEM3 & Mound3_1 & -27.7394 & -156.8234 & 171 & 8.6 & 0.050 & 67.3 & 0.2 & 17.4 & 10.3 \\
\hline DEM3 & Mound3_2 & -27.7409 & -156.8065 & 276 & 27.6 & 0.100 & 75.7 & 0.0 & 19.1 & 10.7 \\
\hline DEM3 & Mound3_3 & -27.7376 & -156.7896 & 205 & 16.6 & 0.081 & 75.0 & 0.1 & 19.8 & 11.0 \\
\hline
\end{tabular}


Table 2 Geometric parameters of 50 mounds measured in this study (Continued)

\begin{tabular}{lllllllllll}
\hline DEM3 & Mound3_4 & -27.7535 & -156.7985 & 186 & 10.6 & 0.057 & 76.6 & 0.1 & 19.4 & 11.3 \\
DEM4 & Mound4_1 & -27.7796 & -156.9253 & 265 & 16.6 & 0.062 & 23.1 & 0.0 & 8.0 & 3.0 \\
DEM4 & Mound4_2 & -27.7784 & -156.9155 & 242 & 17.0 & 0.070 & 31.8 & 0.1 & 8.2 & 3.2 \\
DEM4 & Mound4_3 & -27.7954 & -156.9167 & 203 & 11.5 & 0.057 & 17.6 & 0.1 & 7.0 & 2.5 \\
DEM4 & Mound4_4 & -27.8110 & -156.9188 & 207 & 9.5 & 0.046 & 16.8 & 0.2 & 6.2 & 2.3 \\
DEM4 & Mound4_5 & -27.8032 & -156.8946 & 206 & 13.5 & 0.065 & 20.2 & 0.3 & 8.0 & 2.5 \\
DEM4 & Mound4_6 & -27.8081 & -156.8855 & 147 & 6.0 & 0.041 & 13.8 & 0.1 & 5.4 & 2.0 \\
\hline
\end{tabular}

ArcGIS ArcMap platform, due to its advantage of reducing the measurement errors dependent on different map projections. We then utilized the CraterStats II software (Michael and Neukum 2010) to plot the cumulative form of the CSFD. Absolute model ages are based on the crater production function of (Hartmann and Neukum 2001) with the crater chronology function from (Ivanov 2001). Note that we excluded the craters less than $100 \mathrm{~m}$ in diameter for these plots to decrease the biases influenced by possible overlooking of numerous smaller craters. In the event that small-diameter craters appeared overprinted by resurfacing events (e.g., erosion, mantling), suggested by a distinct "kink" in the CSFD, the resurfacing correction (Michael and Neukum 2010) was also applied to reconstruct the slopes of the CSFD consistent with the isochrons.

\section{Results and discussion}

\section{Geologic classification of the basin floor}

Based on the surface textures and stratigraphic relationships identifiable in HiRISE and CTX images, we classified the basin floor into three geological units (Fig. 2c): (1) upper rugged unit (surface area $=\sim 3500 \mathrm{~km}^{2}$ ) which has a rugged surface with superposed impact craters and the target mounds, (2) lower rugged unit which has a rugged surface with impact craters much more abundant than the overlying upper rugged unit (surface area $=\sim 180 \mathrm{~km}^{2}$ ), (3) lowermost basement unit (surface area $=\sim 530 \mathrm{~km}^{2}$ ) which has rocky hillocks or degraded bedrock interbedded with strata of light-toned layered rocks (Wray et al. 2011) in places. This study focuses on the upper rugged unit which includes all of the targeted mounds.

\section{Distribution of the mounds}

Using the CTX and HiRISE images, we identified a total of 744 mounds from the upper rugged unit (Fig. 2c), giving the mean of their areal density of $\sim 21$ per $100 \mathrm{~km}^{2}$. The resultant map of the identified mound fields shows the coalescence of adjacent mounds (Fig. 3a), the mounds superimposed just on the faults (Figs. 3a, 4c), and the relatively high spatial density of mounds in certain areas (e.g., 61 mounds in a $13 \mathrm{~km}^{2}$ area). Interestingly, in the middle part of the basin floor (Fig. 3c), the four or more individual mounds spacing several hundreds of meters are distributed within the NNE-SSW trending elongated areas, sub-parallel to the long axis of the basin. This characteristic is analogous to the "alignments" of igneous and mud volcanoes on Earth (e.g., Bonini 2012).

\section{Morphology of the mounds}

Observations of HiRISE and CTX images show a variety of morphologies of the mounds. One of the most common characteristics of the mounds is a smooth surface texture relative to the surrounding rugged surface covered with blocky materials and dunes (Fig. 4), whereas brightness of the mound surfaces in visible grayscale images vary in places (Fig. 3). For instance, on the one hand, Fig. 3a reveals that the surface brightness of the mounds are almost uniform and similar to that of the surrounding areas. On the other hand, the mounds at the upper left and bottom of Fig. 3b (only several kilometers apart) show relatively dark and bright surfaces, respectively. These suggest that the materials covering the mound surfaces have different albedos on kilometer scale which may have been influenced by different grain sizes, mineral compositions, states of erosion, and etc. In addition, every mound is superposed on the surrounding terrain, supported by the appearance of smooth mound materials embaying the topographic lows of the surrounding rough surface. Some of the mounds have the circular features (mostly depressions) on their summit (Fig. 4b). Along the rims of these summit pits, clusters of meter-scale boulders can be observed.

Several mounds overlying the fissures (Fig. 4c) show the obvious morphology of deformation or degradation. This may indicate that the formation of these fractures followed the formation of the mounds at least in some locations.

A few mounds exhibit distinct flow-like features along their periphery (e.g., Fig. 4d). This is completely different from the morphology of lobate flow-like extension associated with mass movement because of the absence of typical scarps, ridges, or hummocky surfaces. 


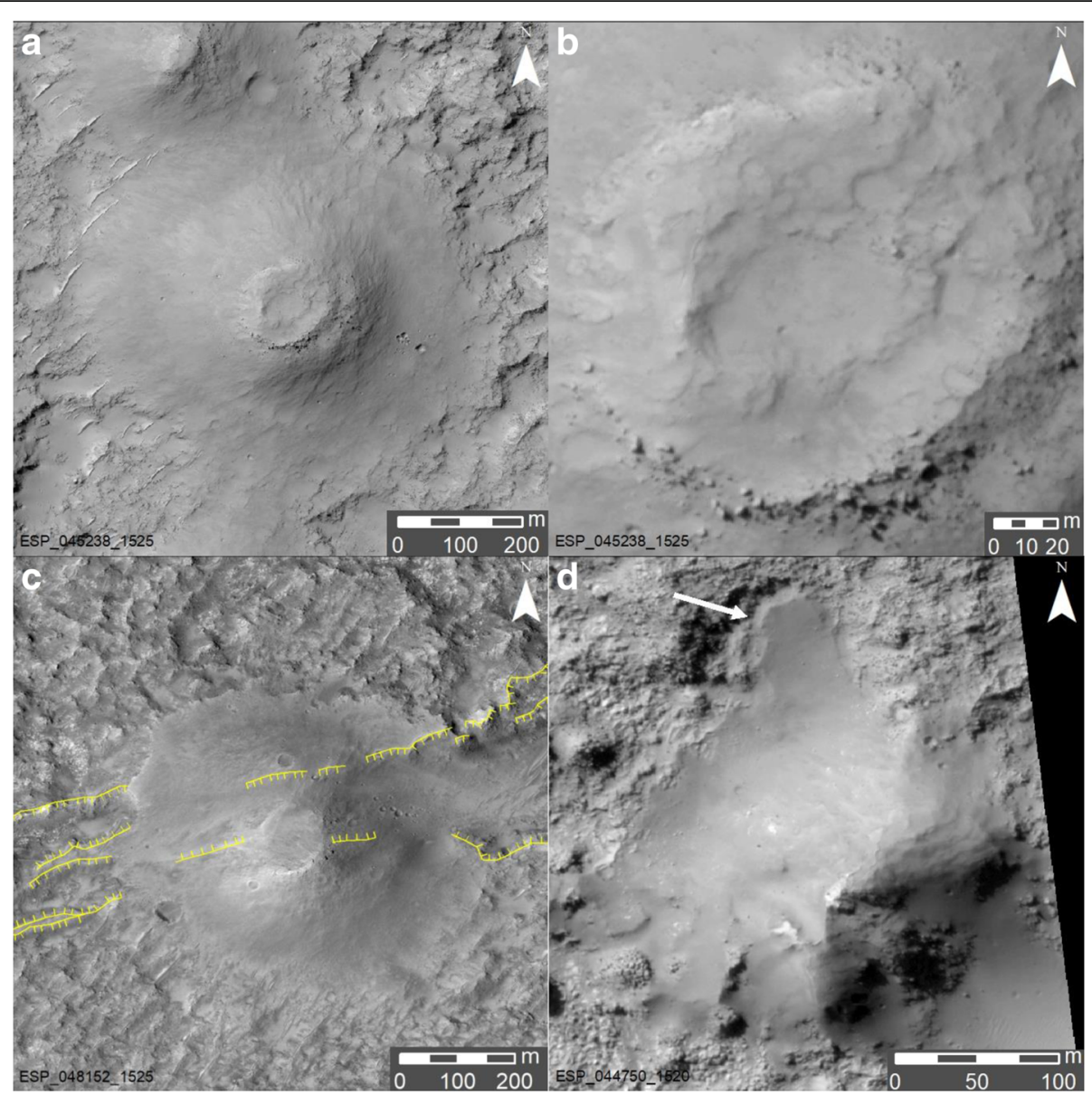

Fig. 4 General morphologic characteristics of the mounds. a Smooth surface texture relative to the surrounding terrain. A circular depression observed on the summit of a mound. Part of HiRISE image with illumination from the upper left. $\mathbf{b}$ Close-up of the summit depression in panel $\mathbf{a}$. Clusters of boulders (up to $6 \mathrm{~m}$ wide) densely distributed along its rim. c A mound deformed by the underlying fissures (yellow lines) determined from the grayscale image and DEM4 (Fig. 5d). Part of HiRISE image with illumination from the upper left. $\mathbf{d}$ Distinct lobate feature $(\sim 70 \mathrm{~m}$ long) along the periphery of a mound (pointed by arrow). Part of HiRISE image with illumination from the upper left

\section{Morphometry and geometry of the mounds}

Morphometric parameters of 50 mounds $(\sim 6.7 \%$ of all the mounds) were measured using the four HiRISEderived DEMs (Fig. 5). We obtained the basal diameters from 147 to $441 \mathrm{~m}$ (mean $=265 \mathrm{~m}$, median $=245 \mathrm{~m}$, $\mathrm{SD}=77)$ and the maximum mound heights from 6.0 to $42.9 \mathrm{~m}$ (mean $=17.8$, median $=16.6, \mathrm{SD}=8.2)$ with the height-to-diameter ratio of 0.034 to 0.10 (see Fig. 6 and Table 2).

Cross-sectional topographic profiles of mounds show that their summits have a wide variety of shapes: cratered summit (e.g., Fig. 7a, b), truncated summit (e.g., Fig. 7c, d), and conical summit (e.g., Fig. 7e, f). Summit depressions on some mounds have depths up to several meters, which bottoms are higher in elevation than the surrounding plains. Flanks of each mound are gently sloping, some of which are characterized by upward convex geometry (Fig. 7b, d). Slope values of each mound suggest that most of the mounds have mean slope values lower than $\sim 10^{\circ}$ (Table 2), except for locations of impact craters and DEM artifacts.

\section{Possible origin of the mounds}

Circular mounds of several hundred meters in diameter sharing similar surface textures as such mounds on Mars can be found on Earth. Proposed terrestrial analog features include impact craters, scoria cones, rootless cones, tuff cones/rings, pingos, and mud volcanoes (e.g., Farrand et al. 2005; Meresse et al. 2008; Burr et al. 2009; de Pablo and Komatsu 2009; Oehler and Allen 2010; Brož et al. 2015).

Impact craters are the sites of past meteor impacts, generally found on planetary surfaces, which is a bowlshaped depression surrounded by raised rims and radially emanating ejecta deposits. Most of the mounds exist in the absence of these characteristics. Though some of 


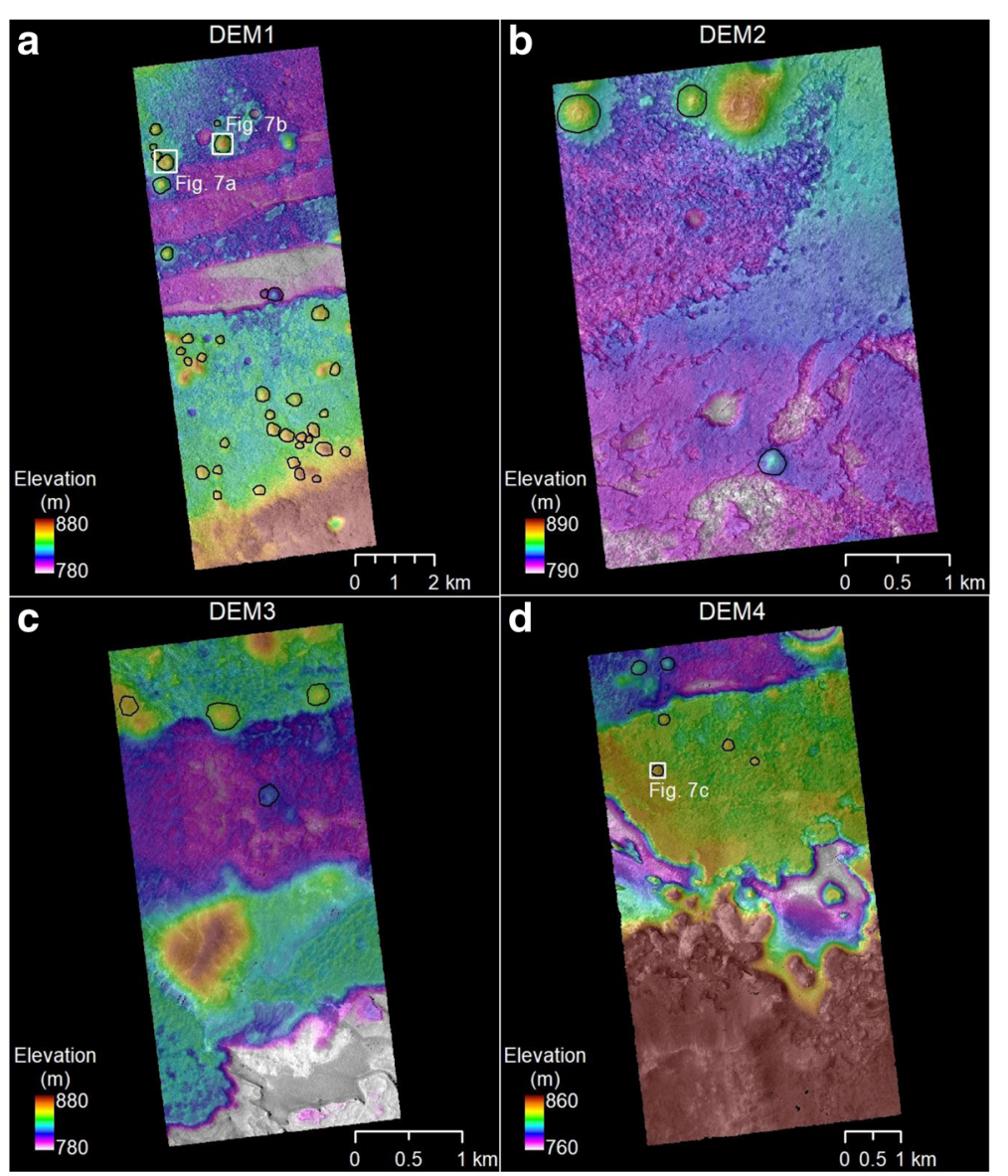

Fig. 5 Four colorized DEMs draped over grayscale orthoimages. a DEM1. b DEM2. c DEM3. d DEM4. Measured mounds are marked by black outlines. See Fig. 2 and Table 1 for their locations and details, respectively

the mounds show the smooth materials overlying the surrounding terrains and distinct crater on the summit with raised rims having ejecta-like boulders (e.g. Fig. 4) similar to the morphology of typical impact craters, the depths of summit depression are too shallow to reach the elevations of the surrounding plains, which is difficult to explain the pitted mounds by the impact origin. We thus concluded that the impact origin is unlikely.

Scoria cones (also known as cinder cones) are the conical volcanic edifices formed by explosive eruptions and associated deposition of pyroclastics around individual vents. Some of the mounds show similar characteristics of typical scoria cones; however, the results of this study are also inconsistent with the scoria cone scenario. Morphology of circular terrestrial scoria cones have the mean basal diameters of $800 \mathrm{~m}$ and mean height of $250 \mathrm{~m}$ (Wood 1979), twice or more larger values than those of the mounds measured in this study (Fig. 8). Moreover, steep or flatfloored summit morphology (Fig. 7) hardly occur on the summit of scoria cones on Earth and Mars.
Associated lava flows found on terrestrial and Martian scoria cones (e.g., Meresse et al. 2008) are also lacking in the mound fields of this study. However, there remains the possibility that later erosional or depositional events deformed the original topography of scoria cones and produced the current morphology and topography, which cannot be conclusively determined without accurate in situ observations.

Rootless cones (or pseudo-craters) are conical or ringlike structures formed by the emplacement of lava flows over wet ground and the subsequent explosions (Greeley and Fagents 2001). Although some of the terrestrial rootless cones have the diameter range comparable to the mounds measured in this study (e.g., Noguchi and Kurita 2015; Fig. 8), there is a critical difference between them: whether mound is made of the same material as that of the surrounding plains or not. Rootless cones are constructed by the pyroclasts sourced from the underlying lava flows, so that if they form on the surface of Mars, little clear contrast in surface albedo between the cones and the surrounding plains is expected to be 


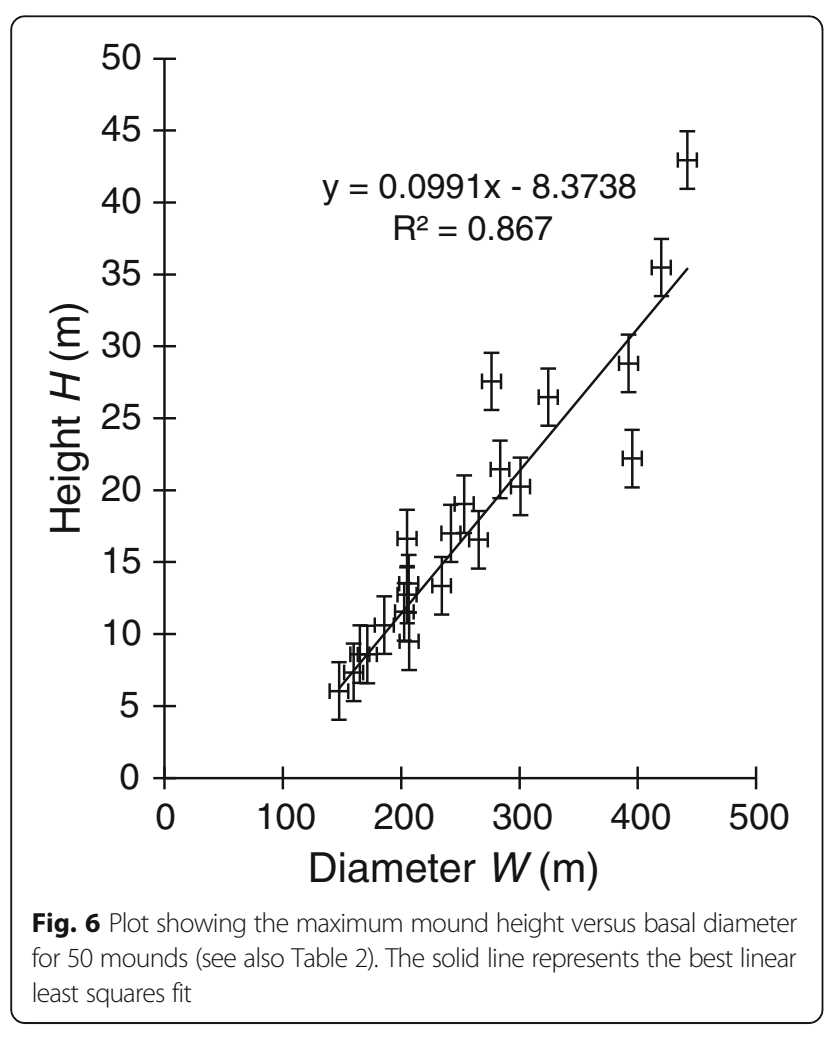

formed due to their similar basaltic compositions. This contradicts that the surface brightness of some mounds differ to that of the surrounding surface in a single observation (e.g., Fig. 3b). Furthermore, terrestrial rootless cones are morphologically composed of central depressions and associated raised rims, which previously proposed rootless cones on Mars exhibit (e.g., Greeley and Fagents 2001); however, some of the studied mounds do not have any summit depression but rather conical summits (e.g., Fig. 7e, f). Thus, it is not reasonable to interpret all of the target mounds as rootless cones.

Pingos are periglacial landforms formed by uplift of the ground surface due to freezing of groundwater, development of subsurface ice lenses, and subsequent increase in bulk volume (Mackay 1979). The morphometry and summit morphology of pingos, as suggested by Jones et al. (2012), are consistent with these of the mounds in our study. However, these processes of pingo formation are expected to produce domical features with same surface textures as the surrounding plains, which is contrary to the difference in surface texture between the mounds and the basin floor (Fig. 3b). In addition, evident fractured surfaces, which pingo candidates on Mars (Dundas and McEwen 2010) exhibit, were not observed in any of the mounds. Martian equivalent also have $175 \mathrm{~m}$ diameter and $\sim 10$ to $\sim 20 \mathrm{~m}$ height (Dundas and McEwen 2010),

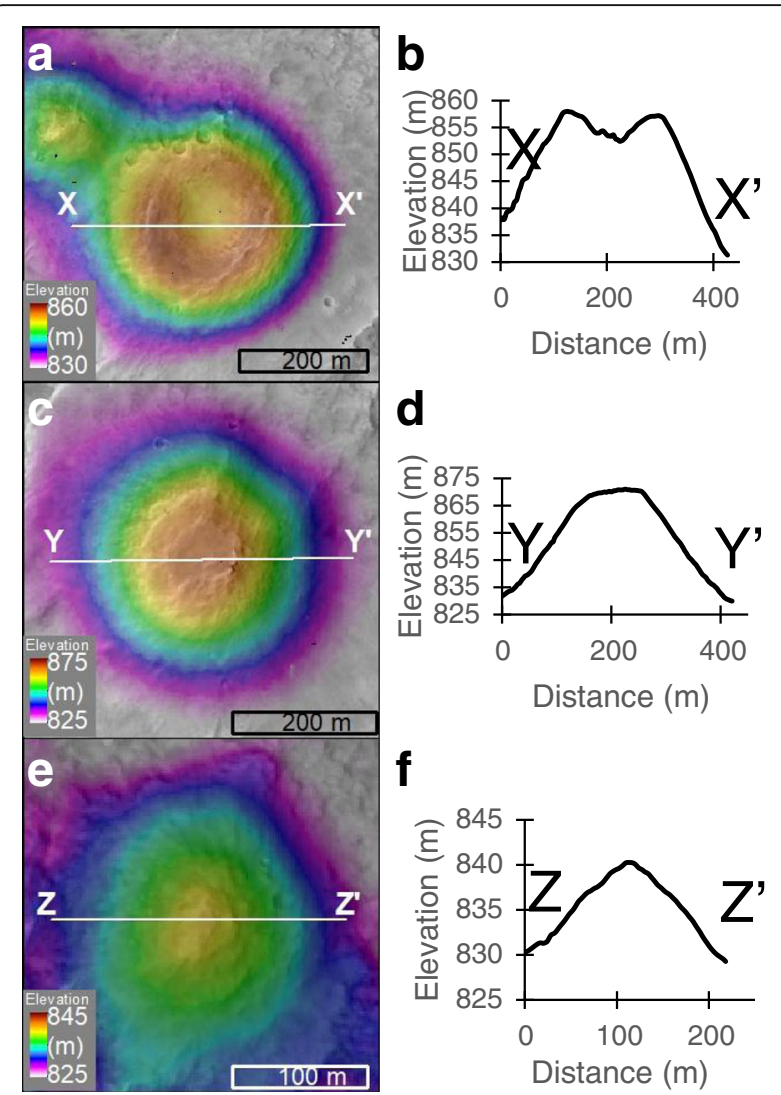

Fig. 7 Topographic profiles of type mounds. a Close-up of a mound in DEM4 (white rectangle in Fig. 5d; mound 4_4 in Table 2). The solid line $X X^{\prime}$ corresponds to the profile in panel $\mathbf{b}$. $\mathbf{b}$ Cross-sectional elevation profile of the mound in panel $\mathbf{a}$. Vertical exaggeration is 10. c Close-up of a mound in DEM1 (white rectangle in Fig. 5b; mound 1_4 in Table 2). The solid line $Y Y^{\prime}$ corresponds to the two profiles in panel $\mathbf{d}$. $\mathbf{d}$ Cross-sectional elevation profiles of the mound in panel c. Vertical exaggeration is 10. e Close-up of a mound in DEM1 (white rectangle in Fig. 5b; mound 1_7 in Table 2). The solid line $Z Z^{\prime}$ corresponds to the two profiles in panel $\mathbf{f}$. $\mathbf{f}$ Cross-sectional elevation profiles of the mound in panel e. Vertical exaggeration is 5

which is slightly higher than the observed mounds with similar diameters in this study. We therefore propose that pingo origin is a less plausible explanation for the formation of the mounds.

Tuff rings, tuff cones, and maars are volcanic craters/ cones with topographic rims, which result from phreatomagmatic explosions (i.e., the interaction between groundwater/standing water and magmatic intrusions). These terrestrial cones/rings and Martian tuff rings/ cones (Brož and Hauber 2013) have basal diameters one or more orders of magnitude larger than the mounds measured in this study (Fig. 8). Furthermore, large summit craters with high crater-to-base ratios (Pike and Clow 1981) are also not common characteristics in the mounds. Therefore, we concluded the phreatomagmatic 


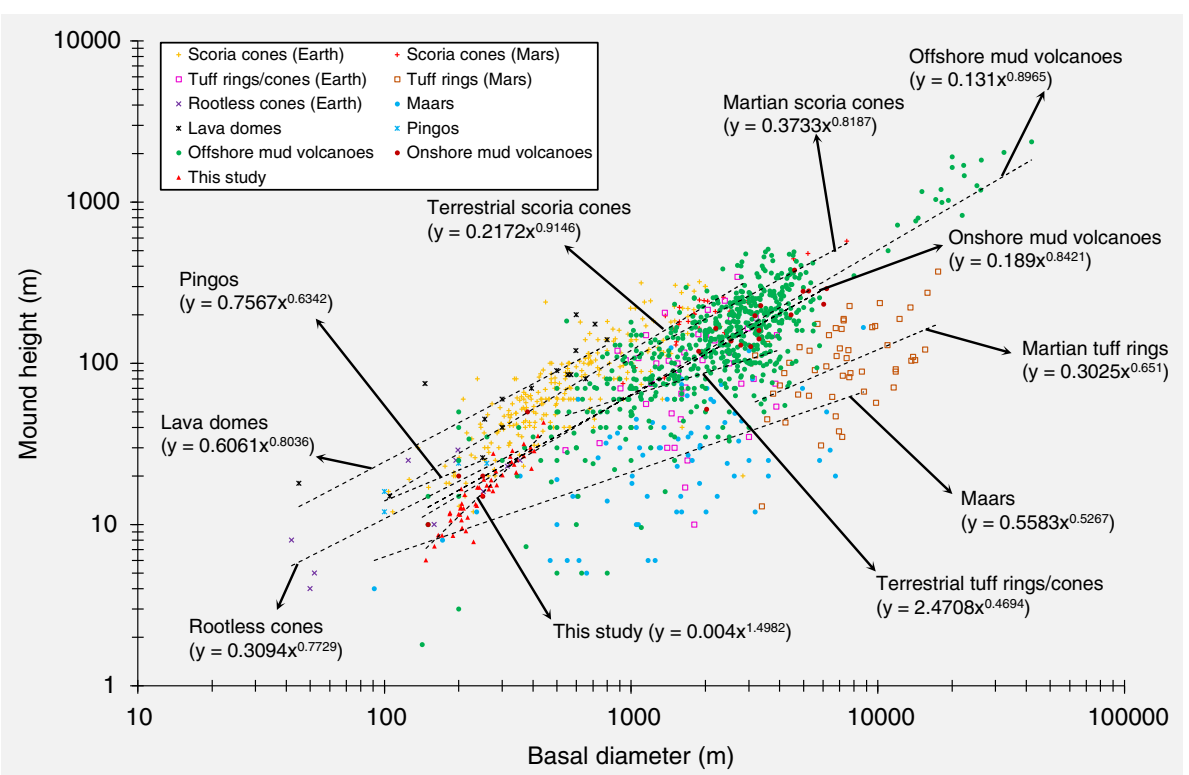

Fig. 8 Morphometric comparison between the measured mounds and other terrestrial analogs. Log-log plots showing mound height versus basal diameter. Dashed lines represent the best linear least squares fits of parameters of each feature. Terrestrial analogs with height and diameter values used for morphometric comparison are offshore mud volcanoes on Earth (Kioka and Ashi 2015; Kirkham et al. 2017), onshore mud volcanoes on Earth (Chigira and Tanaka 1997; Brož and Hauber 2013), potential tuff rings and cones on Mars (Brož and Hauber 2013), potential scoria cones on Mars (Brož et al. 2015), terrestrial maars (Pike 1978), terrestrial lava domes (Pike 1978), terrestrial cinder/scoria cones (Pike 1978; Favalli et al. 2009; Rodríguez et al. 2010), terrestrial pingos (Cabrol et al. 2000), terrestrial tuff rings/cones (Pike 1978), and terrestrial rootless cones (Pike 1978). Morphometric data of elongated (not circular) mounds is not used. Mound maximum height is preferentially used as mound height if available

explosions creating volcanic edifices are less likely origins of the mounds in the basin.

Mud volcanoes are the surface manifestation of mixtures of sediments (e.g., silts, fine sands, brecciated materials) and fluids (i.e., liquid water and gas) migrated upwards from source reservoirs up to several kilometers deep, which can produce a variety of morphologies (e.g., conical mounds, calderas, pools, diapiric intrusions, mud flows) along terrestrial regional compressional fields, mostly subduction zones on a global scale (e.g., Milkov 2000; Kopf 2002). The observations of mound depressions, boulders on the rims, and flow-like features can be interpreted as vent-like structures of the subsurface conduits, mud breccias, and mud flows of typical mud volcanoes on Earth, respectively. The various morphology of cone summits on mud volcanoes in cross-section, reported in Yusifov and Rabinowitz (2004), well correspond to the observations of cone morphologies in Fig. 7.

As summarized in Fig. 8, offshore (submarine) mud volcanoes have the wide range of the morphometric parameters (100 $\mathrm{m}$ to $10 \mathrm{~km}$ in diameter and several meters to kilometers in height), and these are well consistent with those of onshore mud volcanoes. This suggests that the condition of ambient fluid (i.e., air or liquid water) during mound formation do not affect the final size and topography of the mounds critically. In fact, Murton and
Biggs (2003) argued that mud flow spreading across seafloor is driven by the "reduced gravity" $\left(g^{\prime}\right)$ which is proportional to the product of surface gravity and the density contrast between seawater and mud. They theoretically established that the mound radius and height are proportional to the eighth root of $g^{\prime}$ and inversely proportional to the fourth root of $g$, respectively, so that the surface gravity and density (or pressure) of ambient materials are minor contributor relative to the other conditions (e.g., rheology of mud, flow rate, eruption duration). Therefore, if mud volcanoes formed on the free air or underwater conditions of Mars by the eruption of mud having the same flux as the terrestrial ones, they are expected to show similar morphometry to those of both subaqueous and subaerial mud volcanoes on Earth. Importantly, the smaller range of both onshore and offshore mud volcanoes $(\sim 100$ to $\sim 500 \mathrm{~m}$ diameters) have the heights of 1 to $50 \mathrm{~m}$, which is consistent with the heights of the investigated mounds of this study (Fig. 8). Thus, if they are of a mud volcanic origin, both subaerial and subaqueous conditions are possible to explain the origin of the investigated mounds on Mars and difficult to distinguish which condition existed during the periods of mound formation.

The inconsistency between the studied mounds and the other analog features are quite difficult to accurately 
interpret due to different formation ages, different erosion rates, different properties of terrain underlying the mounds (e.g., thickness, bulk soil density), and different surface gravity; however, at least Martian mud volcanoes would not be expected to plot closely with Martian scoria cones, Martian tuff rings/cones, or Martian maars (if existed) in Fig. 8. This is because under low gravity and low atmospheric pressures on Mars surface, larger cone diameters and lower cone heights than those on Earth are expected due to the wider ranges of scoria distribution by far-reaching ballistic emplacement (Wilson and Head 1994; Brož et al. 2015). Actually, the morphometries of candidates of Martian scoria cones (Brož et al. 2015) and Martian tuff rings/cones (Brož and Hauber 2013) are plotted in the larger diameters than the terrestrial equivalents, and they are plotted in different way from that of the observed mounds in this study (Fig. 8). Although the plots in Fig. 8 do not thoroughly compiled all of the previously obtained data, most of the ranges and the trends would not be expected to change significantly. Though exact locations of potential Martian maars have not been reported ever before, they would be expected to be plotted in the larger diameter ranges if they formed on Mars because of the similar mechanism of spatter emplacement to that of scoria cones under low gravity and thinner atmosphere than those of Earth. Data of terrestrial lava domes, terrestrial rootless cones, and terrestrial pingos are not completely compiled in Fig. 8; however, their morphology are completely different from the that of the mud volcanoes and the targeted mounds of this study, so that they are readily discernable even if they have morphometric parameters to those of the studied mounds.

Based on the above discussions, we propose the mud volcanism best explains the origins of the circular mounds in the study area. If such mounds are formed through mud volcanisms, the large amount of clay minerals, aquifers maintained perhaps under moderate heat fluxes, tectonic stresses, and generation of hydrocarbon gases may have occurred within the subsurface below this basin floor for at least limited periods, which would be of great significance in the context of astrobiology. Hence, this basin and mounds can be one of the best candidate sites for future landing exploration.

\section{Surface model age determination}

The cumulative plots of the CSFD, based on the crater counts on the sample region of the southern highlands including the basin (Fig. 9a, b), show the surface model age of $4.0 \mathrm{Ga}$, well consistent with previously described geological units of early Noachian southern highlands (Platz et al. 2013; Tanaka et al.
2014). In contrast, the model age estimates of the upper rugged unit of the basin floor (Fig. 9c, d) is relatively young. A chronology function fitted to the population of impact craters (more than $1.2 \mathrm{~km}$ across) provides the estimated value of $3.5 \mathrm{Ga}$. This age is comparable to the values of some areas of the surrounding highland plains (Platz et al. 2013). In addition, the application of resurfacing correction to the CSFDs of two smaller diameter ranges, 0.6$1.0 \mathrm{~km}$ and $150-500 \mathrm{~m}$, provides the age estimates of $2.9 \mathrm{Ga}$ (Hesperian/Amazonian boundary (Hartmann 2005)) and 1.2 Ga (early Amazonian), respectively (Fig. 9d).

\section{Formational history of the basin environments forming mud volcanoes}

Based on the combinations of model ages and the crosscutting and stratigraphic relationship of geological units and structures, we provide a simple consistent explanation for the formational scenario of Terra Sirenum, the elongated basin, the basin floor, the circular mounds, and the fractures of Memnonia Fossae: (1) heavy bombardment events cratered the northern part of past Terra Sirenum area and formed the chains of several basin structure around $\sim 4.0 \mathrm{Ga}$ (pre-elongated basin), (2) several cratered surfaces were integrated into an elongated trough-like structure at $\sim 3.5 \mathrm{Ga}$ by degradational processes (formation of lowermost basement unit), (3) subsequent infilling of the fluid-laden sediments into the elongated basin, possibly sourced from faults along Memnonia Fossae via upwelling groundwater melted by dike intrusion (Wilson and Head 2002), (4) sedimentary layers with interbedded bright materials (Wray et al. 2011) formed by evaporation (formation of lower rugged unit), (5) local east-west compressional stresses with long-term sediment loading caused overpressurization of groundwater at depth, opened conduits for triggering mud extrusions onto the surface, and deformed some of the mud volcanoes during Hesperian/Amazonian periods, (6) aeolian activities partially buried and excavated the basin interior from Amazonian to date (formation of upper rugged unit).

Additional high-resolution spectral data coverage obtained by the MRO spacecraft in the future will improve mineralogical characterization of the mounds and further discussions of possible diagenetic processes and/ or hydrothermal alteration.

\section{Conclusions}

We examined the distribution, stratigraphic relationship, morphologies, and morphometric parameters of the circular mounds in the elongated basin of the northern Terra Sirenum. Though an eroded volcanic cone origin cannot 


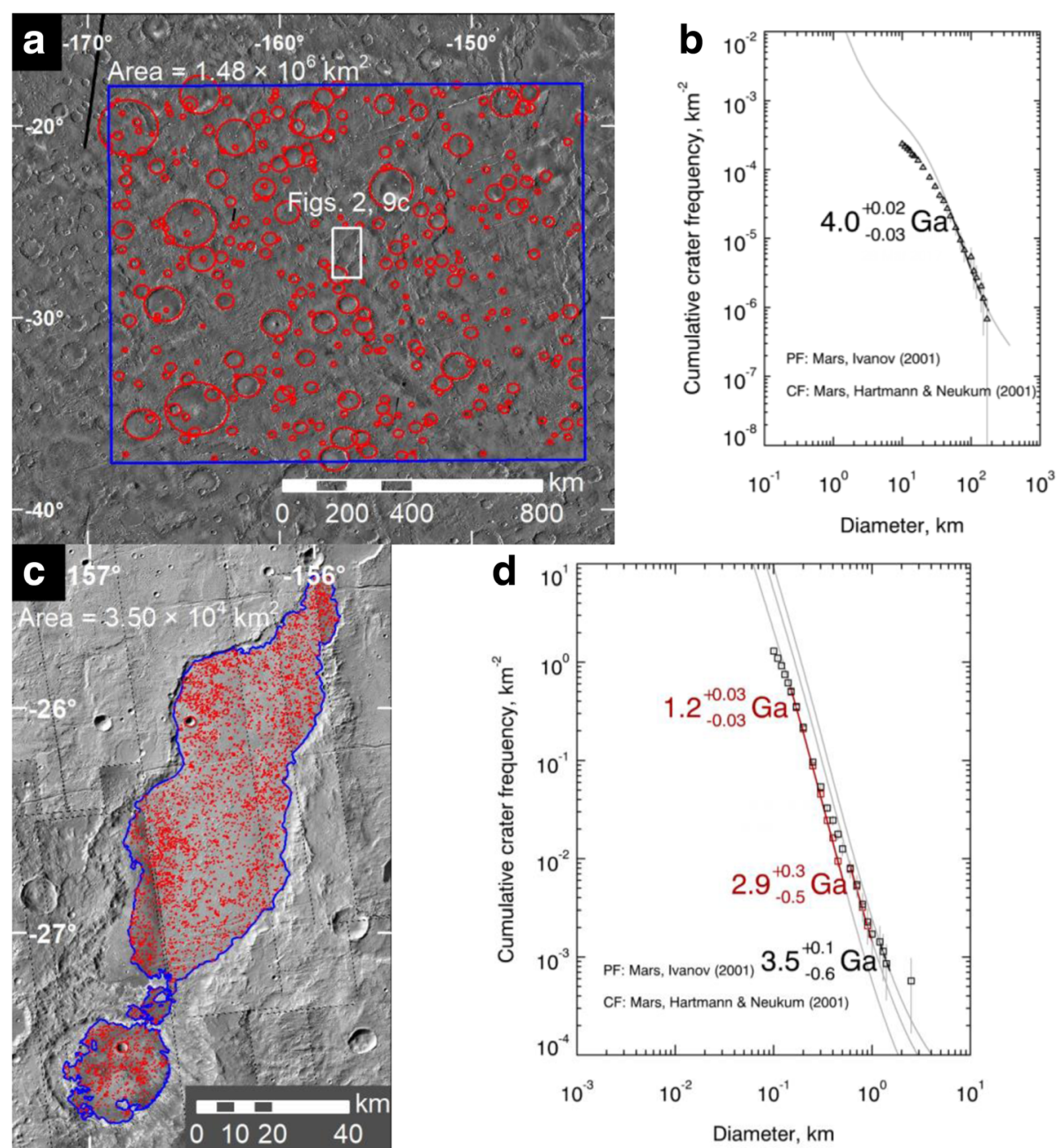

Fig. 9 Crater count-based model age determination. a, b Part of northern Terra Sirenum (Fig. 1) (c, d), the upper rugged unit (Fig. 2c). a Mapped impact craters with diameters $>10 \mathrm{~km}$ (red circles) on a sample region (blue rectangle) surrounding the study area (white rectangle). Base map is from the daytime THEMIS infrared image mosaic (100 m/pixel) which was used to mark the craters. Solar illumination is from the left of the scene. b Cumulative size-frequency plot of the impact craters of $>100 \mathrm{~m}$ diameter $(N=348)$. Production function curve is fitted to the diameter range of 50 to $175 \mathrm{~km}$. c Identified impact craters $>100$ m diameters (red circles, $N=4549$ ) on the upper rugged unit (blue outlines). The CTX image mosaic (base map) was used to map the craters. $\mathbf{d}$ Cumulative crater size-frequency distribution and absolute model ages. Production functions fitted to the three ranges of the crater diameters: 1.2-1.5 km (black), 0.6-1.0 km (red), and 150-500 m (red). Red plots indicate the resurfacing correction (Michael and Neukum 2010)

be ruled out, the combination of their distribution and meter-scale morphology with their morphometry favors a mud volcano origin. If the mud volcano hypothesis is true, their relatively young surfaces suggest that the formation of source reservoirs and conduit openings along regional fissures for erupting mud and groundwater might have occurred during more recent times than Noachian age. This is consistent with other post-Noachian features in the region such as outflow channels which are linked to faults.

\section{Abbreviations}

ASP: Ames Stereo Pipeline; CTX: Context Camera; DEM(s): Digital elevation model(s); GDAL: Geospatial Data Abstraction Library; GIS: Geographic Information System; HiRISE: High Resolution Imaging Science Experiment;
ISIS: Integrated Software for Imagers and Spectrometers; JMARS: Java Mission-planning and Analysis for Remote Sensing; MEGDRs: Mission Experiment Gridded Data Records; MGS: Mars Global Surveyor; MOLA: Mars Orbiter Laser Altimeter; MRO: Mars Reconnaissance Orbiter; NASA: National Aeronautics and Space Administration; PEDRs: Precision Experiment Data Records; THEMIS: Thermal Emission Imaging System; USGS: United States Geological Survey

\section{Acknowledgements}

We thank HiRISE and CTX science teams for producing a number of publicly available, high-resolution image datasets. We also appreciate the developers of USGS's ISIS and Arizona State University's JMARS for enabling us to handle Mars image datasets. We are grateful to NASA Ames Stereo Pipeline developers for creating an open-source software used to generate DEMs. We acknowledge Trent Hare, Elphia Howington-Kraus, Ross Beyer, Oleg Alexandrov, and Zachary Morrato for their helpful comments on DEM extraction and GIS-based processing, and James M. Dohm for preliminary discussions. The detailed reviews by Chris Okubo and an anonymous reviewer improved the clarity of the 
manuscript and are greatly appreciated. This work has been supported by JSPS KAKENHI Grant Numbers 23340126, 25120006, 15K21718, 16K13890, and 17H02953. We appreciate the Space Museum TeNQ/TOKYO DOME CORPORATION for their great support of the branch of Space Exploration, Education, and Discovery (SEED), the University Museum, the University of Tokyo.

\section{Funding}

Not applicable.

\section{Authors' contributions}

$\mathrm{RH}$ proposed the topic, conceived and designed the study, analyzed the data, and interpreted the results. HM collaborated with RH in the discussion and construction of the manuscript. All authors read and approved the final manuscript.

\section{Competing interests}

The authors declare that they have no competing interest.

\section{Publisher's Note}

Springer Nature remains neutral with regard to jurisdictional claims in published maps and institutional affiliations.

\section{Received: 31 March 2017 Accepted: 31 August 2017}

\section{Published online: 11 September 2017}

\section{References}

Becker KJ, Archinal BA, Hare TH, Kirk RL, Howington-Kraus E, Robinson MS, Rosiek MR (2015) Criteria for automated identification of stereo image pairs. In: Abstracts of the 46th Lunar and Planetary Science Conference, 2015, The Woodlands, Texas, p 2703.

Beddingfield CB, Burr DM, Emery JP (2015) Fault geometries on Uranus' satellite Miranda: implications for internal structure and heat flow. Icarus 247:35-52. doi:10.1016/j.icarus.2014.09.048

Beyer RA, Alexandrov O, Moratto ZM (2014) Aligning terrain model and laser altimeter point clouds with the Ames Stereo Pipeline. In: Abstracts of the 45th Lunar and Planetary Science Conference, 2014, The Woodlands, Texas, p 2902

Bonini M (2012) Mud volcanoes: indicators of stress orientation and tectonic controls. Earth Sci Rev 115:121-152. doi:10.1016/j.earscirev.2012.09.002

Broxton MJ, Edwards $\sqcup$ (2008) The Ames Stereo Pipeline: automated 3D surface reconstruction from orbital imagery. In: Abstracts of the 39th Lunar and Planetary Science Conference, 2008, League City, Texas, p 2419

Brož P, Hauber E (2013) Hydrovolcanic tuff rings and cones as indicators for phreatomagmatic explosive eruptions on Mars. Journal of Geophysical Research: Planets 118:1656-1675. doi:10.1002/jgre.20120

Brož P, Čadek O, Hauber E, Rossi AP (2015) Scoria cones on Mars: Detailed investigation of morphometry based on high-resolution digital elevation models. Journal of Geophysical Research: Planets 120:1512-1527. doi:10.1002/ 2015JE004873

Burr DM, Bruno BC, Lanagan PD, Glaze LS, Jaeger WL, Soare RJ, Tseung J-MWB, Skinner JA, Baloga SM (2009) Mesoscale raised rim depressions (MRRDs) on Earth: a review of the characteristics, processes, and spatial distributions of analogs for Mars. Planet Space Sci 57:579-596. doi:10.1016/j.pss.2008.11.011

Cabrol NA, Grin EA, Pollard WH (2000) Possible frost mounds in an ancient Martian lake bed. Icarus 145:91-107. doi:10.1006/icar.1999.6326

Chigira M, Tanaka K (1997) Structural features and the history of mud volcanoes in southern Hokkaido, northern Japan. J Geol Soc Jpn 103:781-791. doi:10.5575/geosoc. 103.781

Christensen PR, Jakosky BM, Kieffer HH, Malin MC, McSween HY, Nealson K, Mehall GL, Silverman SH, Ferry S, Caplinger M (2004) The Thermal Emission Imaging System (THEMIS) for the Mars 2001 Odyssey Mission. Space Sci Rev 110:85-130. doi:10.1023/B:SPAC.0000021008.16305.94

Clifford SM, Parker TJ (2001) The evolution of the Martian hydrosphere: implications for the fate of a primordial ocean and the current state of the northern plains. Icarus 154:40-79. doi:10.1006/icar.2001.6671

de Pablo MÁ, Komatsu G (2009) Possible pingo fields in the Utopia basin, Mars: geological and climatical implications. Icarus 199:49-74. doi10.1016/j.icarus.2008.09.007

Dundas CM, McEwen AS (2010) An assessment of evidence for pingos on Mars using HiRISE. Icarus 205:244-258. doi:10.1016/j.icarus.2009.02.020

Ehlmann BL, Berger G, Mangold N, Michalski JR, Catling DC, Ruff SW, Chassefière E, Niles PB, Chevrier V, Poulet F (2013) Geochemical consequences of widespread clay mineral formation in Mars' ancient crust. Space Sci Rev 174: 329-364. doi:10.1007/s11214-012-9930-0

Farrand WH, Gaddis LR, Keszthelyi L (2005) Pitted cones and domes on Mars: observations in Acidalia Planitia and Cydonia Mensae using MOC, THEMIS, and TES data. Journal of Geophysical Research: Planets 110:E05005. doi:10.1029/2004JE002297

Favalli M, Karátson D, Mazzarini F, Pareschi MT, Boschi E (2009) Morphometry of scoria cones located on a volcano flank: a case study from Mt. Etna (Italy), based on high-resolution LiDAR data. J Volcanol Geotherm Res 186:320-330. doi:10.1016/j.jvolgeores.2009.07.011

Fergason RL, Lee EM, Weller L (2013) THEMIS geodetically controlled mosaics of Mars. In: Abstracts of the 44th Lunar and Planetary Science Conference, 2013, The Woodlands, Texas, p 1642

Glotch TD, Bandfield JL, Tornabene LL, Jensen HB, Seelos FP (2010) Distribution and formation of chlorides and phyllosilicates in Terra Sirenum, Mars. Geophys Res Lett 37:L16202. doi:10.1029/2010GL044557

Greeley R, Fagents SA (2001) Icelandic pseudocraters as analogs to some volcanic cones on Mars. Journal of Geophysical Research: Planets 106:20527-20546. doi:10.1029/2000JE001378

Crater Analysis Techniques Working Group (1979) Standard techniques for presentation and analysis of crater size-frequency data. Icarus 37:467-474. doi:10.1016/0019-1035(79)90009-5

Hartmann WK (2005) Martian cratering 8: isochron refinement and the chronology of Mars. Icarus 174:294-320. doi:10.1016/j.icarus.2004.11.023

Hartmann WK, Neukum G (2001) Cratering chronology and the evolution of Mars. Space Sci Rev 96:165-194. https://doi.org/10.1023/A:1011945222010

Head JW, Kreslavsky MA, Pratt S (2002) Northern lowlands of Mars: evidence for widespread volcanic flooding and tectonic deformation in the Hesperian Period. Journal of Geophysical Research: Planets 107:3-1-3-29. doi:10.1029/2000JE001445

Ivanov BA (2001) Mars/moon cratering rate ratio estimates. Space Sci Rev 96:87104. doi:10.1023/A:1011941121102

Jones BM, Grosse G, Hinkel KM, Arp CD, Walker S, Beck RA, Galloway JP (2012) Assessment of pingo distribution and morphometry using an IfSAR derived digital surface model, western Arctic Coastal Plain, Northern Alaska. Geomorphology 138:1-14. doi:10.1016/.geomorph.2011.08.007

Kioka A, Ashi J (2015) Episodic massive mud eruptions from submarine mud volcanoes examined through topographical signatures. Geophys Res Lett 42: 8406-8414. doi:10.1002/2015GL065713

Kirk RL, Howington-Kraus E, Rosiek MR, Anderson JA, Archinal BA, Becker KJ, Cook DA, Galuszka DM, Geissler PE, Hare TM, Holmberg IM, Keszthelyi LP, Redding BL, Delamere WA, Gallagher D, Chapel JD, Eliason EM, King R, McEwen AS (2008) Ultrahigh resolution topographic mapping of Mars with MRO HiRISE stereo images: meter-scale slopes of candidate Phoenix landing sites. Journal of Geophysical Research: Planets 113:E00A24. doi:10.1029/2007JE003000

Kirkham C, Cartwright J, Hermanrud C, Jebsen C (2017) The spatial, temporal and volumetric analysis of a large mud volcano province within the Eastern Mediterranean. Mar Pet Geol 81:1-16. doi:10.1016/j.marpetgeo.2016.12.026

Kneissl T, van Gasselt S, Neukum G (2011) Map-projection-independent crater size-frequency determination in GIS environments-new software tool for ArcGIS. Planet Space Sci 59:1243-1254. doi:10.1016/j.pss.2010.03.015

Kopf AJ (2002) Significance of mud volcanism. Rev Geophys 40:2-1-2-52. doi:10.1029/2000RG000093

Mackay JR (1979) Pingos of the Tuktoyaktuk peninsula area, Northwest territories. Géog Phys Quatern 33:3-61. doi:10.7202/1000322ar

Malin MC, Bell JF, Cantor BA, Caplinger MA, Calvin WM, Clancy RT, Edgett KS, Edwards L, Haberle RM, James PB, Lee SW, Ravine MA, Thomas PC, Wolff MJ (2007) Context Camera investigation on board the Mars Reconnaissance Orbiter. Journal of Geophysical Research: Planets 112:E05S04. doi:10.1029/2006JE002808

McEwen AS, Eliason EM, Bergstrom JW, Bridges NT, Hansen CJ, Delamere WA, Grant JA, Gulick VC, Herkenhoff KE, Keszthelyi L, Kirk RL, Mellon MT, Squyres SW, Thomas N, Weitz CM (2007) Mars Reconnaissance Orbiter's High Resolution Imaging Science Experiment (HiRISE). Journal of Geophysical Research: Planets 112:E05S02. doi:10.1029/2005JE002605

Meresse S, Costard F, Mangold N, Masson P, Neukum G (2008) Formation and evolution of the chaotic terrains by subsidence and magmatism: Hydraotes Chaos, Mars. Icarus 194:487-500. doi:10.1016/j.icarus.2007.10.023

Michael GG, Neukum G (2010) Planetary surface dating from crater size-frequency distribution measurements: partial resurfacing events and statistical age uncertainty. Earth Planet Sci Lett 294:223-229. doi:10.1016/j.epsl.2009.12.041 
Michalski JR, Dobrea EZN, Niles PB, Cuadros J (2017) Ancient hydrothermal seafloor deposits in Eridania basin on Mars. Nat Commun 8:15978. doi:10.1038/ncomms15978

Milkov AV (2000) Worldwide distribution of submarine mud volcanoes and associated gas hydrates. Mar Geol 167:29-42. doi:10.1016/S0025-3227(00)00022-0

Moratto ZM, Broxton MJ, Beyer RA, Lundy M, Husmann K (2010) Ames Stereo Pipeline, NASA's open source automated stereogrammetry software. In: Abstracts of the 41st Lunar and Planetary Science Conference, 2010, The Woodlands, Texas, p 2364

Murton BJ, Biggs J (2003) Numerical modelling of mud volcanoes and their flows using constraints from the Gulf of Cadiz. Mar Geol 195:223-236. doi:10.1016/ S0025-3227(02)00690-4

Noguchi R, Kurita K (2015) Unique characteristics of cones in Central Elysium Planitia, Mars. Planet Space Sci 111:44-54. doi:10.1016/j.pss.2015.03.007

Oehler DZ, Allen CC (2010) Evidence for pervasive mud volcanism in Acidalia Planitia, Mars. Icarus 208:636-657. doi:10.1016/j.icarus.2010.03.031

Okubo CH (2016) Morphologic evidence of subsurface sediment mobilization and mud volcanism in Candor and Coprates Chasmata, Valles Marineris, Mars. Icarus 269:23-37. doi:10.1016/j.icarus.2015.12.051

Pike RJ (1978) Volcanoes on the inner planets: some preliminary comparisons of gross topography. In: Proceedings of the 9th Lunar and Planetary Science Conference, 1978, Houston, Texas, pp 3239-3273.

Pike RJ, Clow GD (1981) Revised classification of terrestrial volcanoes and catalog of topographic dimensions, with new results of edifice volume. U. S. Geological Survey Open-File Report 81-1038

Platz T, Michael G, Tanaka KL, Skinner JA, Fortezzo CM (2013) Crater-based dating of geological units on Mars: methods and application for the new global geological map. Icarus 225:806-827. doi:10.1016/j.icarus.2013.04.021

Pondrelli M, Rossi AP, Ori GG, Van Gasselt S, Praeg D, Ceramicola S (2011) Mud volcanoes in the geologic record of Mars: the case of Firsoff crater. Earth Planet Sci Lett 304:511-519. doi:10.1016/j.epsl.2011.02.027

Rodríguez SR, Morales-Barrera W, Layer P, González-Mercado E (2010) A quaternary monogenetic volcanic field in the Xalapa region, eastern trans-Mexican volcanic belt: geology, distribution and morphology of the volcanic vents. J Volcanol Geotherm Res 197:149-166. doi:10.1016/j. jvolgeores.2009.08.003

Shean DE, Alexandrov O, Moratto ZM, Smith BE, Joughin IR, Porter C, Morin P (2016) An automated, open-source pipeline for mass production of digital elevation models (DEMs) from very-high-resolution commercial stereo satellite imagery. ISPRS J Photogramm Remote Sens 116:101-117. doi:1016/j.isprsjprs.2016.03.012

Smith DE, Zuber MT, Frey HV, Garvin JB, Head JW, Muhleman DO, Pettengill GH, Phillips RJ, Solomon SC, Zwally HJ (2001) Mars Orbiter Laser Altimeter: experiment summary after the first year of global mapping of Mars. Journal of Geophysical Research: Planets 106:23689-23722. doi:10.1029/2000JE001364

Tanaka KL, Chapman MG (1990) The relation of catastrophic flooding of Mangala Valles, Mars, to faulting of Memnonia Fossae and Tharsis Volcanism. J Geophys Res Solid Earth 95:14315-14323. doi:10.1029/JB095iB09p14315

Tanaka KL, Skinner JA, Hare TM (2005) Geologic map of the northern plains of Mars. In: U.S. Geological Survey Scientific Investigations Map 2888

Tanaka KL, Skinner JAJ, Dohm JM, Irwin lii RP, Kolb EJ, Fortezzo CM, Platz T, Michael GG, Hare T (2014) Geologic map of Mars, Scale 1:20,000,000. In: U.S. Geological Survey Scientific Investigations Map 3292.

Wilson L, Head JW (1994) Mars: review and analysis of volcanic eruption theory and relationships to observed landforms. Rev Geophys 32:221-263. doi:10. 1029/94RG01113

Wilson L, Head JW (2002) Tharsis-radial graben systems as the surface manifestation of plume-related dike intrusion complexes: models and implications. Journal of Geophysical Research: Planets 107:1-1-1-24. doi:10. 1029/2001JE001593

Wood CA (1979) Monogenetic volcanoes of the terrestrial planets. In: Proceedings of the 10th Lunar and Planetary Science Conference, 1979, Houston, Texas, pp 2815-2840.

Wray JJ, Milliken RE, Dundas CM, Swayze GA, Andrews-Hanna JC, Baldridge AM, Chojnacki M, Bishop JL, Ehlmann BL, Murchie SL, Clark RN, Seelos FP, Tornabene LL, Squyres SW (2011) Columbus crater and other possible groundwater-fed paleolakes of Terra Sirenum, Mars. Journal of Geophysical Research: Planets 116:E01001. doi:10.1029/2010JE003694

Yusifov M, Rabinowitz PD (2004) Classification of mud volcanoes in the South Caspian Basin, offshore Azerbaijan. Mar Pet Geol 21:965-975. doi:10.1016/j.marpetgeo.2004.06.002

\section{Submit your manuscript to a SpringerOpen ${ }^{\circ}$ journal and benefit from:}

- Convenient online submission

- Rigorous peer review

- Open access: articles freely available online

- High visibility within the field

- Retaining the copyright to your article

Submit your next manuscript at $>$ springeropen.com 